\title{
Post-War Livelihood Development in Batticaloa District, Sri Lanka
}

\author{
Suresh Kanesh $^{1}$ and Mumthaj Sameem ${ }^{2}$ \\ ${ }^{1}$ Senior Lecturer, ${ }^{2}$ Deputy Registrar, Eastern University, Sri Lanka \\ E-Mail: sureshmax@ hotmail.com
}

\begin{abstract}
This paper examines the post war livelihood development in Batticaloa district, in the East coast of Sri Lanka. Batticaloa has been ravaged three decades of civil war and end of war the district has been emerging the development path. This paper discusses trends of major livelihood recovery of the district,fishing, agriculture, tourism and financial sector development in the district. Number of developments programmes initiated by the successive governments and international organizations in the district. This study measures the stakeholder perspectives of the livelihood recovery of the district. The study used primary data from more than 200 sample respondents and interviews with relevant stakeholders. The study revealed that major livelihood such as fishing and agriculture improved slightly since end of the war 2009. However, lack of financial support and basic infrastructure hinder the livelihood initiatives. Study further revealed that the absent of small industries or factories in the district causes persistent youth unemployment.
\end{abstract}

Keywords: Livelihood, Conflict, Poverty, Development, Batticaloa District

\section{INTRODUCTION}

The communities in the war-affected areas of Batticaloa are considered 'livelihoods at risk': people face multiple challenges which make them vulnerable. Householdshave to adapt to gradual deteriorating economic trends and to cope with sudden political shocks in the form of violence (Korf and Silva 2003). Conflict, economic and political instability, and disasters are often responsible for forced displacement, denial of basic human rights, and deliberate destruction of livelihoods of the people.The end of the civil war (2009) in Sri Lanka that ravaged the country for nearly three decades signaled the emergence of a new era in Sri Lanka in relation to: building of peace and reconciliation between the communities, Sinhalese, Tamils and Muslims and the rebuilding of the county's economy as well as economic regeneration of the North and East that suffered severe damage and destruction in the consequences of the war. Poverty in North and East is much higher than the national average (Balakrishnan, 2010) because people were denied access to basic needs such as water and electricity and the disruption of welfare services that were once available. According to the Central Bank report, 2\% to 3\% of the GDP estimate, the country would have lost annually during the thirty years conflict (Development Policy Review, 2009).

After three decades of prolonged war in Sri Lanka the Government, Non-Governmental organizations and International community have been provided assistance to the war-affected communities for their livelihood development. However, there has been no significant improvement in livelihood activities of war victims (Sarvananthan, 2009). It clearly shows that there need to be improvements in income level, wellbeing, vulnerability, food security and sustainable use of natural resources.As mentioned above the proximate causes of deteriorating of livelihood in the conflict affected Batticaloa district of Sri Lanka yet to be explored. Hence, a need for a critical research to understanding the key factors which affecting livelihood development, and to assess the impacts of policy interventions in a situation of conflict is vital. It is a key challenge to assess how people manage to survive and to pursue their livelihoods in the day to day life and to verify how individuals or communities make use of assets, social structures and institutions. Another important issue is that how to design effective policy strategies for the vulnerable groups belonging to the multi-ethnic, multi-religious society to ensure the reconstruction of their livelihood in the post conflict situation.

The study seeks to understand strategies which have been formed by the stakeholders and coping by people to achieve livelihood sustainability in the context of post-war development in the Batticaloa district of Sri Lanka.

Goodhand (2001) et al., compared the livelihood strategies of four locations in the war affected, multi-ethnic Trincomalee district in Sri Lanka. Here, many people have returned to their place of origin and have re-established some form of livelihoods after the war. Although the article compares livelihoods of different ethnic communities in various agro-ecological zones, all four cases have in common that they located in disputed areas with a great degree of random violence and instability. The findings suggest two propositions: first, livelihood strategies are deeply contextual and depending on the local political geography of war. Hence, we can observe a large variation of livelihood outcomes across the cases. Furthermore, from a perspective of winners and losers, war can be both a threat and an opportunity, often at the same time (Korf, 2002). The findings of the study (Korf, 2002) indicate that livelihood strategies and outcomes in the war zones of Sri Lanka are highly complex, contextual and dynamic. One should be careful in making sweeping generalizations across cases and groups, and in relating all behaviour and livelihood strategies solely to impacts of the ongoing conflict. The findings broadly suggest that households need to exercise a great degree of flexibility in working with their assets in order to secure their livelihoods in times of war. The 
challenges posed to households have also altered intrahousehold gender roles, particularly in Tamil Society, where women have to take a more active role in economic activities.

\section{THEORETICAL BACKGROUND}

\section{A. Sustainable Livelihoods, Conflict, and Poverty}

The concept of sustainable livelihoods, which had first appeared in the research literature in the 1980s, had become in the late 1990s one of a trio of principle foundation of UK development policy and the basis for a number of DFID programmes and practices (Twigg, 2001). The most known definition of a sustainable livelihood comes from Chambers and Conway (1992) and a modified version of the definition has been generally adopted, with minor differences between authors and organizations. According to Scoones and Carney (1998) 'A livelihood comprises the capabilities, assets (including both material and social resources) and activities required for a means of living. A livelihood is sustainable when it can cope with and recover from stresses and shocks, maintain or enhance its capabilities and assets, both now and in the future, while not undermining the natural resource base'. According to Ellis (2000) livelihoods comprise the assets, activities, and the access to these that together determine the living gained by the individual or household. Ellis in his definition has placed more emphasis on the access to assets and activities that is influenced by social relations and institutions. The concept of livelihoods is directly opposed to the traditional economic focus of development on income and employment, because neither of those concepts accurately captured the elements upon which poor people build their lives (Schafer, 2002).

In conflict situations, the Sustainable Livelihood Approach (SLA) needs to be modified to emphasize the vulnerability of people exposed to constant threats of violence and displacement. Displacement tends to aggravate existing vulnerabilities and create new forms. Social groups that are politically or economically marginalized find themselves at double risk when they are displaced and have even more difficulty pursuing livelihoods. Taking into consideration the increased risk of the entire community, a 'livelihoods in conflict' approach de-emphasizes the sustainability part of the livelihoods framework and emphasizes the need to reduce vulnerability and risk that occurs as a result of conflict (Jacobsen.K, 2002). Such a definition might be as follows: In communities facing conflict and displacement, livelihoods comprise the ways in which people access and mobilize resources that enable them to increase their economic security and thereby reduce the vulnerability created and exacerbated by conflict, and pursue goals necessary for their survival and possible return.
The key element of SLA is that people are the starting point. According to Ashley and Carney (1999) the SLA is a way of thinking about the objectives, range and priorities for development, in order to enhance progress in poverty reduction; and placing people and their priorities at the centre of the analysis. Ellis describes the commonly accepted core of sustainable livelihood thinking as "the requirement to understand and act upon the asset limitations of the poor, the risks they confront, and the institutional environment that either facilitates or blocks them in their own endeavors to build pathways out of poverty" (Ellis 2002). The promotion of sustainable livelihoods is one way of achieving poverty reduction. The SLA provides an analytical framework that promotes systematic analysis of the underlying processes and causes of poverty. It is not the only such framework, but its advantages are that it focuses attention on people's own definitions of poverty and takes into account a wide range of factors that cause or contribute to poverty. Definition and interpretation of poverty varied over time and space due to differences in political, economic, cultural and ecological conditions of the contexts in question. There is consensus on that; poverty has fundamentally to do with deprivation (Chambers, 1995). According to Chambers, deprivation refers to lacking what is needed for well-being. Its dimensions are physical, social, economic, political, and psychological. A positive state of well-being may be thought of as an expression of human capabilities of doing and being; where doinginvolves agency, choice and freedom, and being involves welfare and happiness. The SLA approach attempts to capture this in the notion of outcomes that people are trying to achieve through their livelihood strategies. The strategies includes more income, increased well-being, reduced vulnerability, improved food security and more sustainable use of natural resource base (DFID, 2000)

There have been discussions within development studies linking poverty and conflict, Goodhand has reviewed this literature and presents three different views in this concern: conflict causes poverty; poverty causes conflict; and resource wealth causes conflict (Goodhand 2001, Schafer 2002). There is some agreement on the hypothesis that conflict causes poverty. The impact of conflict depends on the level of compensatory action by national governments or the international community. However, internal war is likely to produce chronic poverty. Violent conflict has led to a high number of death and displaced people, material destruction and even state collapse. It destroys years of investment and development efforts (Goodhand 2001). In my research I will build upon the various definitions of sustainable livelihoods and the discussions on post conflict and poverty to develop an operational and analytical definition for the study of livelihoods in the post conflict era. My starting point will be the Sustainable Livelihoods Approach and, on the basis,, formulate an analytical framework for the research. 


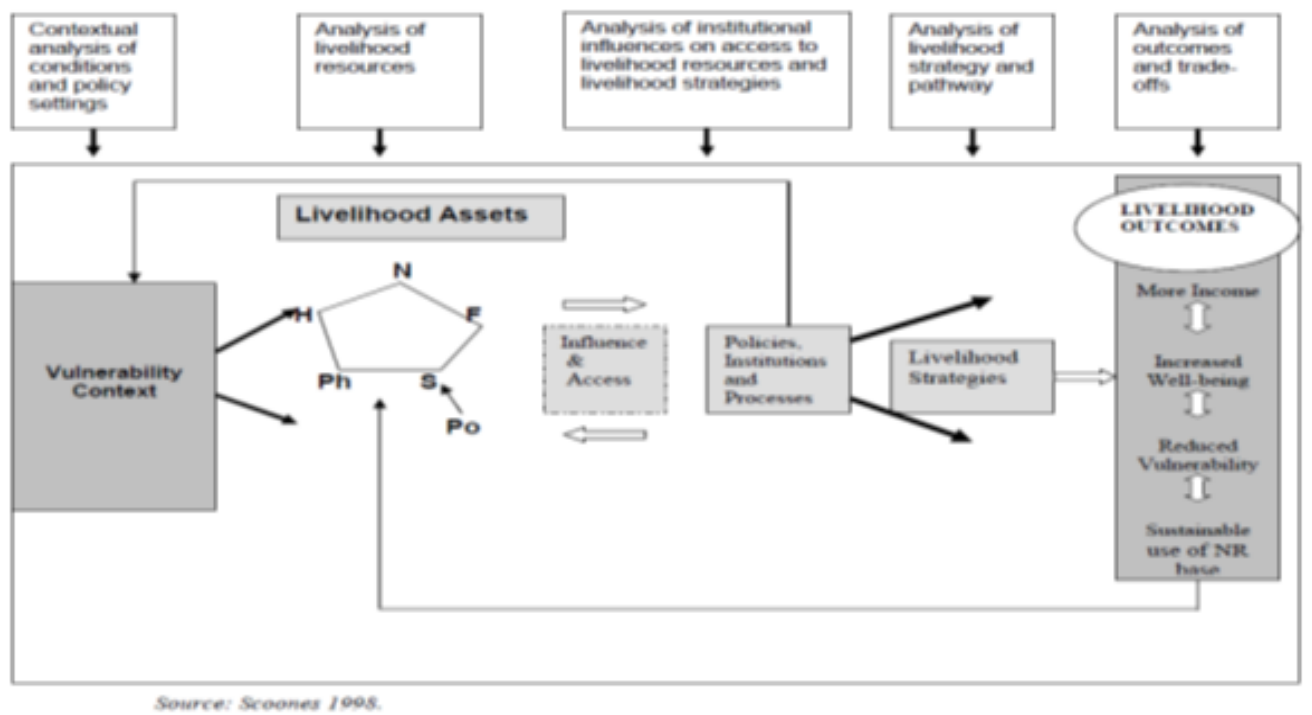

Fig. 1 Sustainable livelihood framework

The LSA puts strong emphasis on the question of sustainability in the economic, environmental and social well-being of people, governance and policy as well as their linkages. It uses empowerment rather than welfare. As part of the empowerment of a community, the sustainable livelihoods approach allows for the development of indicators to measure improvements in livelihood systems and the sustainability of these systems. It mainly deals with (i) contextual analysis of conditions and policy settings, (ii) analysis of livelihood resources, (iii) analysis of institutional influences on access to livelihood resources and on livelihood strategies, (iv) analysis of livelihood strategy and pathway, and (v) analysis of outcomes and trade-offs. The above investigation will pave the way to examine how people cope with the increased probability of negative consequences for personal lives imposed by the brutal and insecurity environment of the civil war, and also to find different strategies of organizing the livelihood assets within a person, household, and community.

\section{METHODS}

Data collected for primary and secondary sources used structured questionnaires. The primary data gathered through field study. The research locations were selected within the identified clusters from different geographical areas of the Batticaloa district of Sri Lanka which were affected by the civil war for 30 years.In addition to the primary data, the secondary data were also used from published and unpublished documents, agency reports, articles, internet sources and government statistical reports for this study.

\section{SAMPLE AND STUDY AREA}

This research was carried out in the Batticaloa District of Sri Lanka, where the livelihoods of the people have been seriously affected by continuing inter-ethnic conflicts for over two decades and the tsunami catastrophe. The district is ethnically mixed, being home to people from all three major ethnic groups, viz. Sinhalese (1.3\%), Tamils (75.2\%), and Muslims $(23.5 \%)$ which are causes for mounting ethnic tensionsThisdistrict comprises of 14 divisional secretariat divisions major portion of the population is engaged in agriculture while the fishing occupies the second place in the economy of the district. Other occupations are industrial activities, business and employment in government, corporation and private establishments. The district has about 30,000 agriculture families and about 16,300 fishing families.

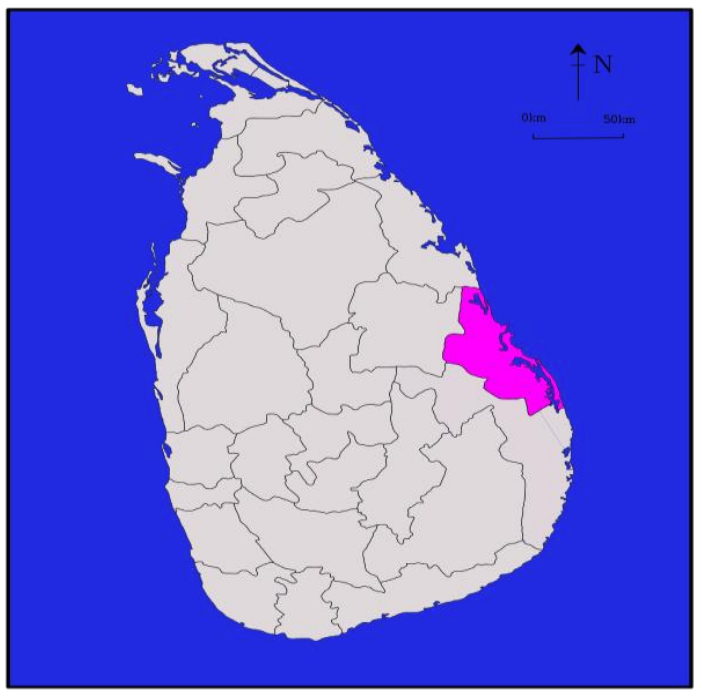

Source: District secretariat Batticaloa, 2017

Fig. 2 Batticaloa District of Sri Lanka

The total coastline population of 74,307 is multi ethnic and distributed in the district. A sample of 250 household was selected for the study and we received 237 useable responses. We use simple random sampling. Structured questionnaires were used for the study. Interviews and focus group discussion were applied in the study. 


\section{DISCUSSIONS}

The major livelihood of the people in the district; farming, fishing, wage labour and few of them engaging in livestock. Other sources of income government employments and remittances from individual working Middle-East countries. The substantial economic decline during the war in the Eastern province (Silva et al., 2018). The number of postwar livelihood issues were identified such less agricultural efficiency, poor fishing harvest, poor infrastructure facilities, absence of private sector initiatives, in the region still abandoned cultivatable plots in Batticaloa district.

Pre-war period in Batticaloa district has many factories such as tile factory in Vahari, Rice mill, paper mill in Valachenai which provided job opportunities for locals because of the $30 y e a r s$ of war they were shut down these factories and many people lost their jobs. Since end of the war in 2006, no government initiatives had to reestablish those factories in the region. Unemployment and poverty in the district recorded first in the Sri Lanka due to the war.

Many irrigation canals and rural road damaged by the war yet to be renovated and external market has hampered due to poor road networks (Silva et al., 2018). Pre-war period most of the agricultural land were used for two seasonal cultivation, whereas, recent days farmers only cultivates one season using rain harvest due to lack of irrigated water. Climate change impact is one of the significant issues in the district frequent flood $(2005,2010,2011,2016)$ and droughts which create massive productivity losses and make farmers in to 'debt trap'. Farmers are losing their profits due to middle men during their harvesting season, in the season paddy price drops sharply and poor farmers they do not have proper storage facilities therefore they compel to sell their output at a low rate.

The fishing industry plays a vital role in Batticaloa districts and around 25,000 families engages in fishing activities. The industry has boost in the post war development by removing deep sea fishing which was banned by the government due to security reason. However, fishing industry yet to be achieved potential level and facing numerous challenges storage facilities, most of the fisherman are boat workers rather than owners (Silva et al., 2018). The private sector investment is very low compared with other nations in multiday vessels and using modern equipment's for fishing.

Human- elephant conflict (HEC) threats local livelihood in many areas of the Batticaloa district. Several studies have found that the average damage to the crop land was estimated at about 1.2 acre per household per annum, which accounts for nearly 22 percent of the district crop area. HEC caused not only direct cost to the farmers but also, various indirect cost, such as decline in sleeping, employment, and education of the children.
The continuous crisis of the war in the past three decades limited the financial service outcomes at various levels in the North and East. Considering the security of the banks, the Ministry of Finance through the Central Bank of Sri Lanka has granted approval to extend limited services in the North and East provinces. In the year 2006, there were 450 bank branches including extension offices in the North and East. This number increased to 640 in the third quarter of 2009, showing a 56 percent growth. Further, in the first half of the year 2016, twenty new banking outlets in the North and 51 new banking outlets in the East were established.

The tourism sector along with other productive sectors in Batticaloa was affected by the persistent insecurity and conflict, leading to the loss of investments and jobs in the sector. Post -war tourism sector development in the Batticaloa district is emerging and promising sector in livelihood development of local community. A number of hotels have been immerged in the district. But the trained employees in the tourism sector and the value addition to the sector is still lacking.

\section{CONCLUSION}

Effective policy strategies for protecting livelihoods in post conflict environments can be formulated with having clear understanding of the post conflict situations. The great majority of victims are suffering from hunger, malnutrition, and disease. Therefore, the mitigation of the human cost of post conflict and the improvement of livelihood are inevitable. Our studyrevealed that livelihood of households in post conflict situation and also, will offer insights into the impact of household livelihood programmes, communitywide programmes and social programmes. However, there need to be more attention to be paid in Batticaloa because poverty is still higher than the national poverty line in the district. This will offer further learning on livelihood strategies particularly information on how people cope with increased probability of negative consequences for personal lives. And also it will provide tools to engage how individuals or communities make use of structures and processes, and how they are accessible to the people in the region.Therefore, this study expected to generate and provide inside information to policy makers and other domestic and external actors to allocate funds and other resources in a way in which to maintain a balance in affected people's livelihoods in conflict affected areas.

\section{REFERENCES}

[1] Ashley, C. \& Carney D. (1999). Sustainable Livelihoods: Lessons from early experience. London, DFID, Department for International Development.

[2] Balakrishnan, N. (2010). Post war development in North and East Sri Lanka, International symposium, EUSL.

[3] Bebbington A. (1999). Capital and Capabilities: A Framework for Analyzing Peasant Viability, Rural Livelihood and Poverty, World Development, 27(12).

[4] BenediktKorf. (2002). War and Livelihoods and Vulnerability in Sri Lanka. 
[5] (5)Carney D. (1998). Sustainable Rural Livelihoods: Department for International Development, London.

[6] CathrineBrun and Ragnhild Lund. (2008).Making a home during crisis: post tsunami in a context of war, Sri Lanka. Singapore Journal of tropical Geography, 29.

[7] Central Bank of Sri Lanka, (2009). Annual Report.

[8] Cernea M. (2000). Risks, safeguards and reconstruction: a model for population displacement and resettlement' in Cernea, M.M and McDowell, C. (eds): Washington DC, World Bank.

[9] Chambers R. (1995). Poverty and Livelihoods: Whose Reality Counts?' IDS Discussion.

[10] Chambers, R. \& Conway G. (1992). Sustainable Rural Livelihoods: Practical Concepts for the 21st Century. IDS Discussion Paper 296. Brighton: IDS

[11] DCSSL (2009). Department of Census and Statistics, Sri Lanka.

[12] Denzin, N. K., \& Lincoln, Y.S. (Eds.). (1994). Handbook of Qualitative Research. Thousand Oaks, CA: Sage.

[13] DER (2000). A Framework for Poverty Reduction in Sri Lanka, Colombo: Department of External Resources, Government of Sri Lanka.

[14] Devereux.S. (2001). Livelihood Insecurity and Social Protection: A re-emerging Issue in Rural Development. Development Policy Review, 19(4).

[15] DFID, (2000). Sustainable Livelihoods Guidance Sheets: Department for International Development, London.

[16] Ellis, F. (2002). Introduction to K Hussein, Livelihoods approaches compared: A multi-agency review of current practice, DFID and ODI, London.
[17] Ellis, F. (2000). Rural Livelihoods and Diversity in Developing Countries. Oxford: University Press.

[18] Goodhand, J. (2001). Violent Conflict, Poverty and Chronic Poverty, Chronic Poverty Research Centre Paper No. 6, Manchester: Chronic Poverty Research Centre.

[19] Goodhand, Jonathan. (2000). Research in Conflict Zones: Ethics and Accountability. Forced Migration Review, 8.

[20] Karen Jacobsen. (2002). Livelihood in conflict, International migration, 40(5), 95-123.

[21] Kelegama, Saman. (1999). Economic Cost of Conflict in Sri Lanka in Rotberg, R.I., ed 1999. Creating Peace in Sri Lanka. Washington DC: Brookings Institution Press.

[22] Korf B. and K.T. Silva. (2003). Poverty, Ethnicity and Conflict in Sri Lanka, Paper presented at the conference Staying Poor: Chronic Poverty and Development Policy' University of Manchester.

[23] Sarvananthan, M. (2003). Economic revival in North and East Sri Lanka: what are the Impediments?.Economic and Political Weekly, $38(19)$.

[24] Schafer, J. (2002). Working Paper 183: Supporting Livelihoods in Situations of Chronic.

[25] Scoones Ian. (1998). Sustainable rural livelihoods: a framework for analysis, IDS, working paper, 72.

[26] Twigg, J. (2001). Sustainable Livelihoods and Vulnerability to Disaster', Benfield Greig Hazard Research Centre, Disaster Management working paper.

[27] UNDP, (1998). National Human Development Report - Sri Lanka. 